\title{
Evaluation of Changes in Blood Factors and Thyroid hormones in radiology students of Kurdistan University of Medical Sciences
}

Atefeh Moradi ${ }^{1}$, Sahar Babarashi ${ }^{2}$, Nayer Seyfizadeh ${ }^{3}$, Farzaneh Zareai ${ }^{4}$, Masood Moradi ${ }^{5}$, Mona Amani ${ }^{6}$, Farideh Elahimanesh ${ }^{7}$

1. M.Sc. Student, Department of Medical and Engineering Physics, Medicine „Iran University of Medical Sciences, Tehran, Iran, ORCID ID: 0000-0002-4359-5783. Medicine, Iran

2. Bachler Student, Student Research Committee, Kurdistan University of Medical Sciences, Sanandaj, Iran, ORCID ID: 0000-0002-2449-7686.

3. Ph.D. of Biochemistry, Stem Cell Research Center, Tabriz University of Medical Sciences, Tabriz, Iran, ORCID ID: 00000001-9744-7252.

4. Instructor, Department of Emergency Medical Sciences, Faculty of Paramedical Science, Kurdistan University of Medical Sciences, Sanandaj, Iran, ORCID ID: 0000-0003-0607-3035.

5. M.Sc. of Biostatistics, Vice Chancellor for Research and Technology, Kurdistan University of Medical Sciences, Sanandaj, Iran, ORCID ID: 0000-0002-7813-9518.

6. Bachler Student, Student Research Committee, Kurdistan University of Medical Sciences, Sanandaj, Iran, ORCID ID: 0000-0001-7790-7241.

7. Instructor, Department of Radiology, Faculty of Paramedical Science, Kurdistan University of Medical Sciences, Sanandaj, Iran, (Corresponding Author), Email: f.elahimanesh@gmail.com, Tel :087-33660084. ORCID ID: 0000-00018744-8251.

\begin{abstract}
Background and Aim: X - ray and gamma ray are part of the electromagnetic waves that can penetrate into living tissues, ionizing radiation can Lead to abnormal function. Despite radiology students could be exposed to ionization radiation during received training, their radiation dose has not evaluated. The purpose of this study was to compare the blood factors and thyroid hormones in the senior and freshman radiology students

Materials and Methods: case -control study was performed in may-July 2018 . the sample size was consisted of 60 freshman and senior radiology students (30 freshman and 30 senior radiology students) who were healthy and have not has blood diseases. Eventually, The blood factors of students was analyzed in the laboratory .

Results : measuring blood factors such as white blood cell, erythrocyte, basophil, neutrophil,platelet, hemoglobin but the mean basophil ,lymphocyte, T4 and TSH showed that Ionizing radiation causes significant changes in basophil, lymphocytes and thyroid hormones (T4 and TSH ) in two group of students, but there was no significant difference in others blood factors between two group $(\mathrm{P}<0.05)$.

Conclusion : Ionizing radiation caused changes some blood factors ( basophil, lymphocytes and thyroid hormones (T4 and TSH ) ) .therefore, the survey of radiology division and raising safety and awareness of student is recommended.
\end{abstract}

keyword: Ionizing Radiation, Dosimetry, Blood cell, Thyroid

Received: Aug 7, $2019 \quad$ Accepted: July 24, 2020

How to cite the article: Atefeh Moradi, Sahar Babarashi, Nayer Seyfizadeh, Farzaneh Zareai, Masood Moradi, Mona Amani, Farideh Elahimanesh. Evaluation of Changes in Blood Factors and Thyroid hormones in radiology students of Kurdistan University of Medical Sciences. SJKU 2020;26(2):32-40.

Copyright (C) 2018 the Author (s). Published by Kurdistan University of Medical Sciences. This is an open access article distributed under the terms of the Creative Commons Attribution-Non Commercial License 4.0 (CCBYNC), where it is permissible to download, share, remix, transform, and buildup the work provided it is properly cited. The work cannot be used commercially without permission from the journal 


\section{بررسى تغيير ات فاكتورهاى خونى و هور مونهاى تيروئيد در دانشجويان راديولوزى دانشكاه علوم بز شكى كر دستان}

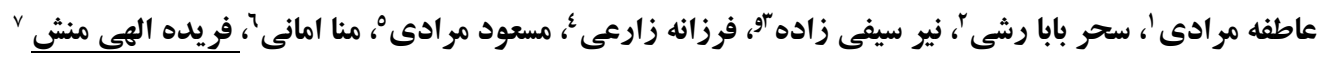

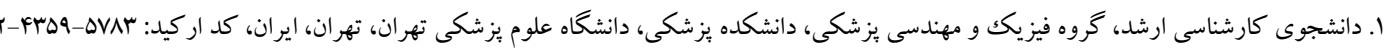

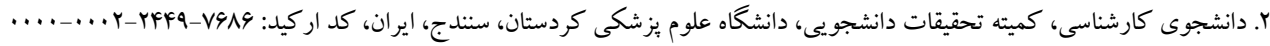

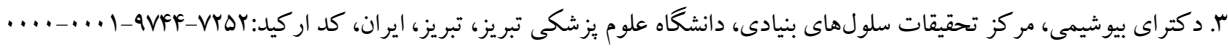

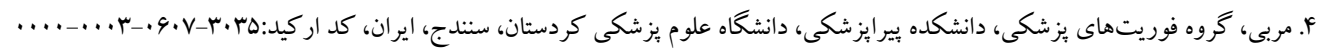

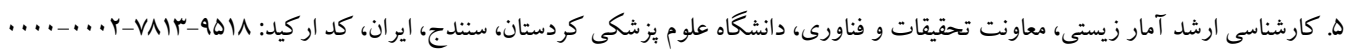

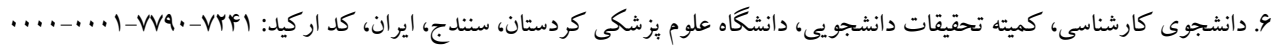

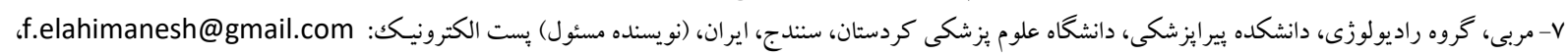
تلفن :

جكکبه

زمينه و هدف: يروتوهاى ايكس و كاما بخشى از طيف امواج الكترومغناطيسى است كه قابليت نفوذ بـه داخـل بافتهـاى زنــه را

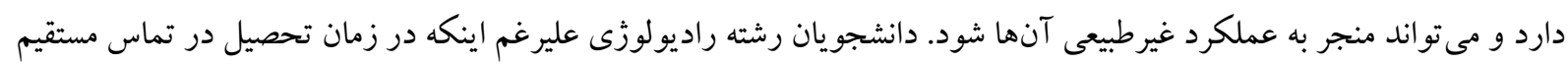

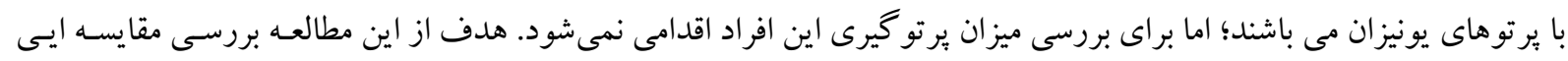

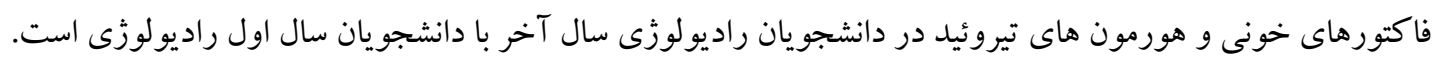

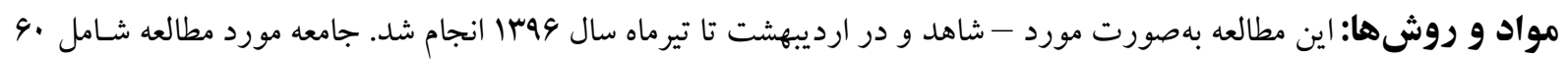

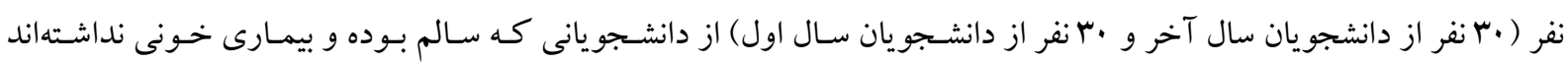
نمونههاى خونى در آزمايشگاه آناليز گرديد.

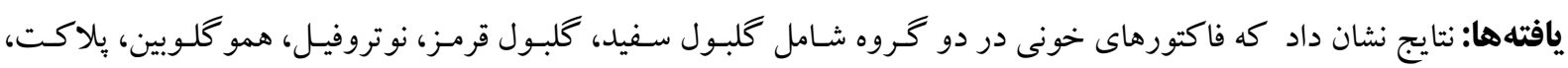

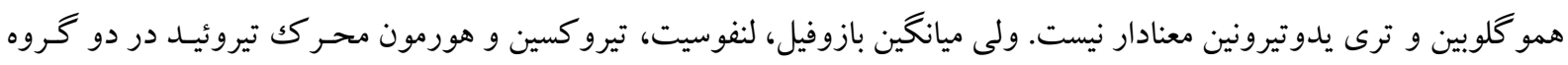

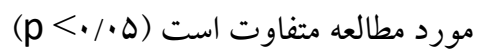
نتيجه كيرى: برتوهاى يونيزان باعث تغيير در فاكتورهاى خونى (بازوفيل، لنفوسيت) و هورمسون تيرو كسين و هورمـون محرك كـ تيروئيد شده است؛ لذا توصيه مى شود جهت افزايش ايمنى دانشجويان يرتو كار در زمان كار آموزى بايستى دوز سنجى اين افراد را جهت بايش مد نظر قرار داد. كلمات كليدى: يرتوهاى يونيزان، دزيمترى، سلول هاى خونى، تيروئيد

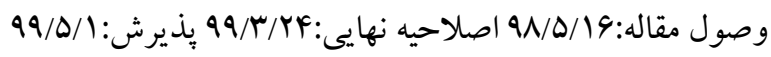


يونيزاسـيون باعـث سـندروم هــاى تشعشعى مسى شـود؛ امـاــا دوزهاى يائين منجر به افزايش آثار احتمالى مانند سرطان در

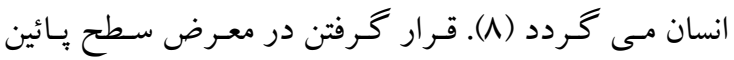
تشعشعات يون ساز به مدت طولانى، فراوانى ناهنجارى هاى

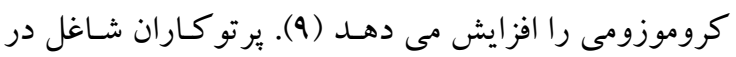

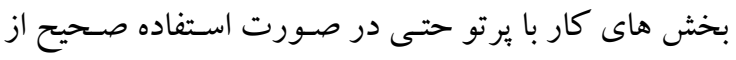
تجهيزات حفاظتى و رعايت قوانين و مبانى حفاظتى بـاز هـم

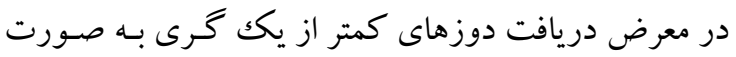

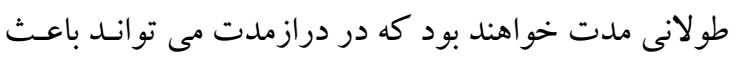

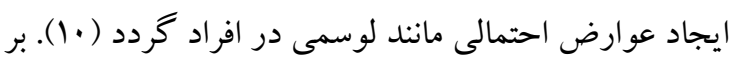
اساس مطالعـات سيتوزنتيكك انجـام شـــه در افراد يُرتو كـار مقدار كم تشعشع، ميزان آسيب هاى كروموزومى را در ايـن

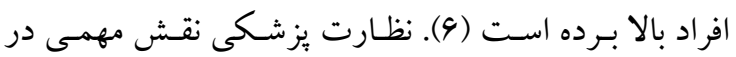
حفاظت از كار كنان در برابر آسيب هاى ناشى از تابش دارد

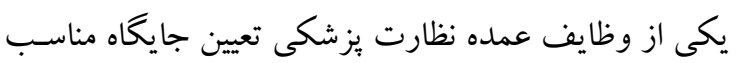
براى يرتو كار بر طبق سوابق بهداشتى و شرايط بدنى آن ها و

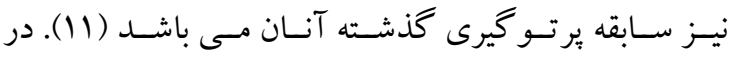

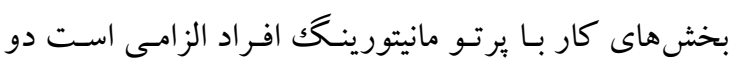

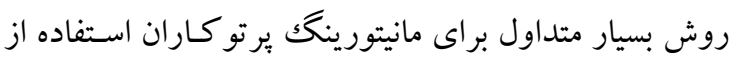

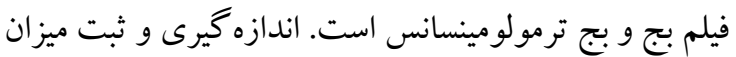

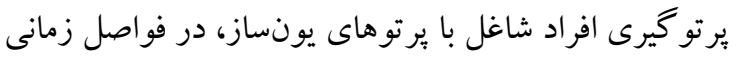
معين الزامى است. در بخشهاى درمانى هر سه ماه يككبار و در بخشهاى تشخيصى هر شش ماه يككبار دوزيمترى افراد

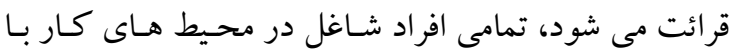
برتو بايد مجهز به دوزيمتر باشـند (YI). بـر اسـاس مطالعـات

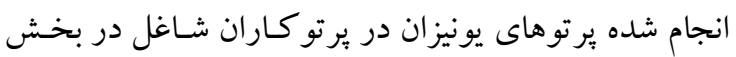
هاى كار با برتو باعث كاهش كلبول هاى سفيد و مونوسيت

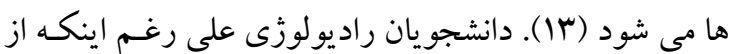

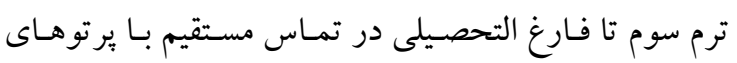

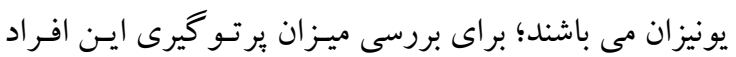

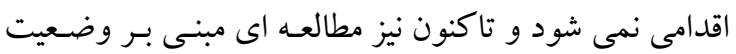

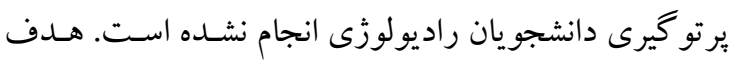
ازاين مطالعه آن است تا ميزان فاكتورهاى خونى و هورمـون

\section{مقلمه}

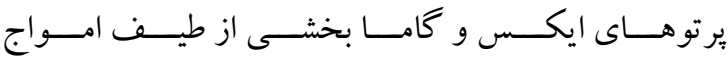

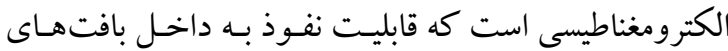
زنده را دارد و مى تواند منجر به تخريـب در بافتهـاى زنـده

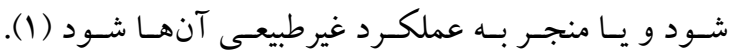

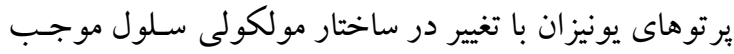
اختلال در عملكرد سلولها يـا جهش آنهـا مسىشـوند (Y). همجنين موجب نايايدارى و صـدمات كرومـوزومى و تغيير

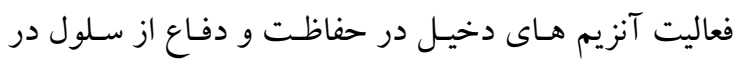

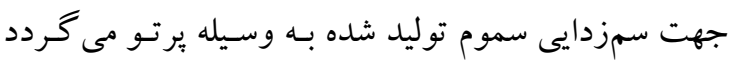

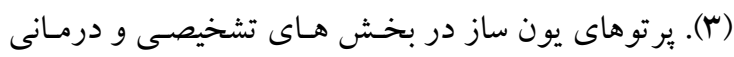

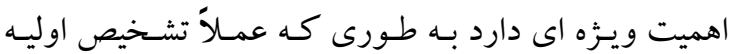

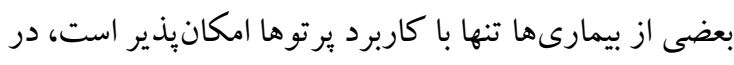

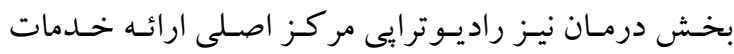

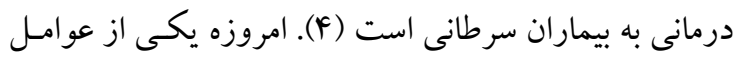

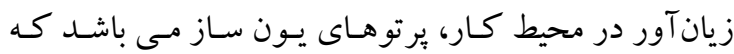
مى تواند باعث آسـيبهاى جـدى و جبـران نإِـذير در افراد يرتو كار و يا افرادى كـه جهـت تشـخص و درمـان مراجعهـ

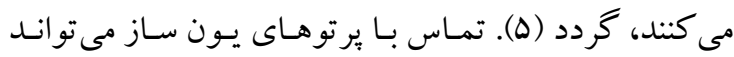
اثراتى بر روى دستخاه خونساز، دستخاه گُوارش و سيستم

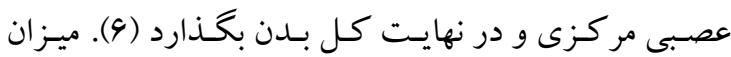

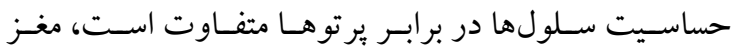
استخوان كه نقش خونسازى را دارد حسـاسترين بافت در برابر اشعه است. در اثر مواجهشدن بـا يرتوهـا در سـلولهاى خونى آسيبهاى كروموزومى ايجاد شده كه اين آسيب هـا

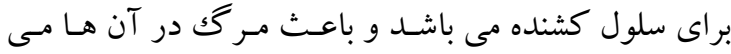
شود در نتيجه تعداد سلول هاى خونى تغييـر ييـا مى كنــا

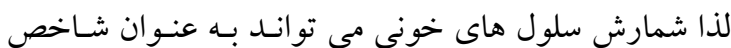

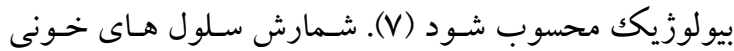
مى تو اند به عنوان ابزارى براى بررسى ميزان آسيب يرتوهاى

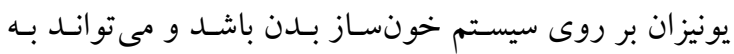

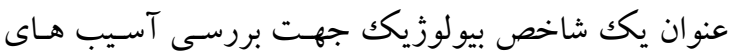

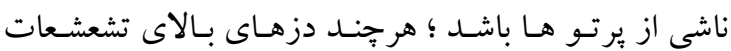


از كيــت hormone, TSH

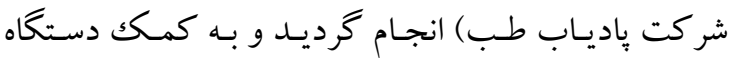

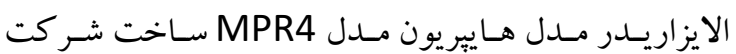

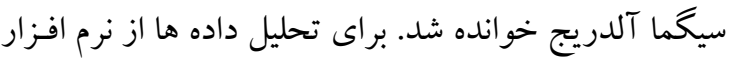

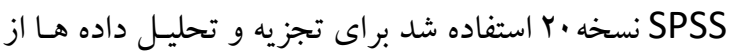

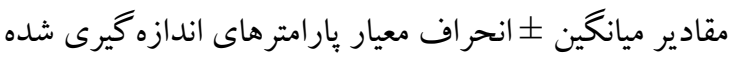

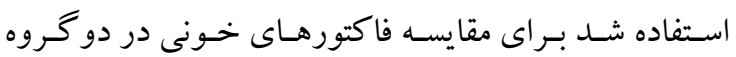

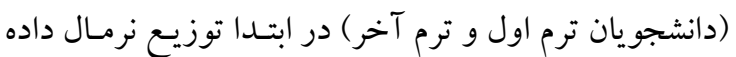

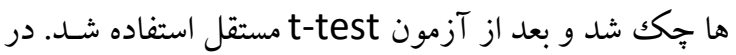

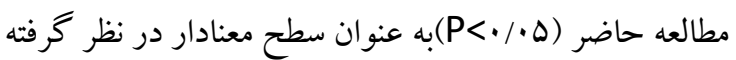

\section{يافتهها}

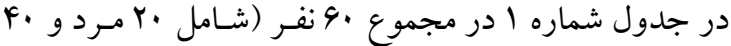
زن) شر كت داشـتند كـه شـامل سم/س درصـد مـورد مـرد و 49/9 درصد مورد زن اسـت و همـانطور كـه ايسن جـدول نشان مىدهد توزيع جنسى در دو گرووه تفـاوت معنىدارى

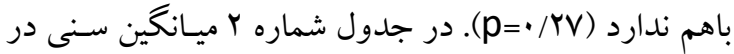
ميان دانشجويان ترم اول Y/9V سـال و در ميـان دانشـويان ترم آخر برابر TV/TV سال بوده است و طبيعتاً ميـانگين سـنى دانشـجويان تـرم آخـر بيشـتر از دانشسجويان تـرم اول اسـت

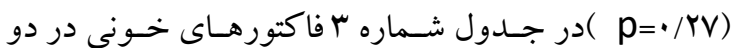

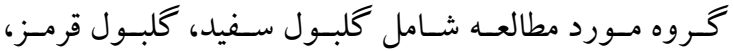
نو تروفيل، همو كلوبين، يلاكـت، همو كلـوبين و T3 معنـادار

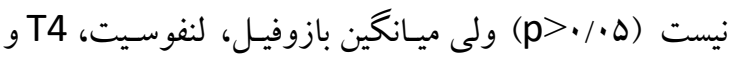
TSH
هاى تيروئيد دانشجويان راديولوزى ترم آخـر بـا دانشسجويان ترم اول راديولوزى مورد سنجش قرار دهيم.

\section{مواد و روش ها}

اين مطالعه بهصورت مقطعى و از ارديبهشت تـا تيرمـاه سـال

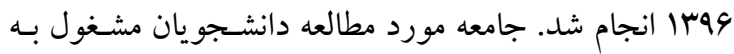
تحصيل در رشته راديولوزى بودنــ. حجـم نمونسه ،و نفـــ از دانشجويانى كه مايل به شركت در مطالعه بودند (كـه شـامل • س نفر از دانشجويان ترم آخر به عنوان گروه مورد بررسى و. • ب نفر از دانشجويان ترم اول به عنوان كروه شـاهد بودنـد).

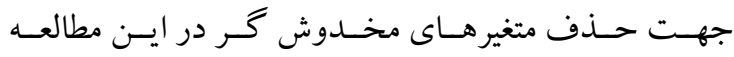
دانشجويانى كـه بيمارىهـاى تيروئيسدى و خـونى داشـتند از مطالعه حذف گرديد دانشجويان مورد مطالعه افرادى سالم و داراى شرايط مناسب مطالعه بودند همجنين در فاصـله شـش ماه اخير هيج گونه سابقه يرتو گيرى بزشكى نداشتهاند. نمونسه خون به ميزان هـ سـ سـى در شـرايط اسـتريل در بيمارستان بعثت سنندج كرفته شد. در نمونه هـاى خـونى كامـل تسـت شـمارش سـلول هـاى خـونى بـه وسـيله دســاه سـل كـانتر سيسمكس مدل kx21n ساخته شده توسط شركت سمكس انجام شد. سـنجش هومـورن هـاى تيروئيــ خـون كامـل بـر دسـتور العمل كيت هـاى مخصـوص سـنجش هورمونهـاى تيروئيدى (جهت سنجش هورمون ترى يدو تيرونين (T3) از كيت PT-EFT3-104 و جهت سنجش هورمون تيروكسين ازكيت PT-EFT4-105 و جهت سـنجش هورمـون (T4)

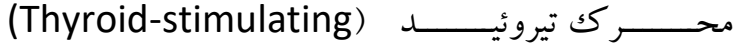

جدول ا. توزيع فراوانى جنسيت در افراد مورد مطالعه به تفكيك ترم تحصيلى. دانشجويان ترم اول به عنوان تروه كنترل بدون

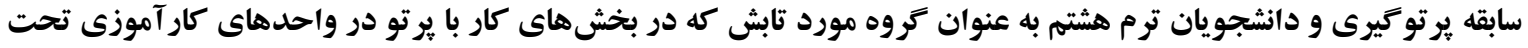

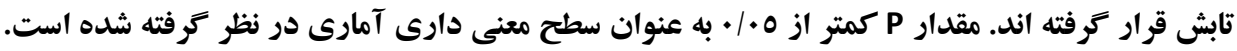
توزيع فراوانى جنسيت در افراد مورد مطالعه به تفكيك ترم تحصيلى

\begin{tabular}{|c|c|c|c|}
\hline & \multicolumn{2}{|c|}{ جنسيت } & \multirow{2}{*}{ ترم تحصيلى } \\
\hline كل & زن & مرد & \\
\hline$r$. & 11 & ir & ترم 1 \\
\hline
\end{tabular}




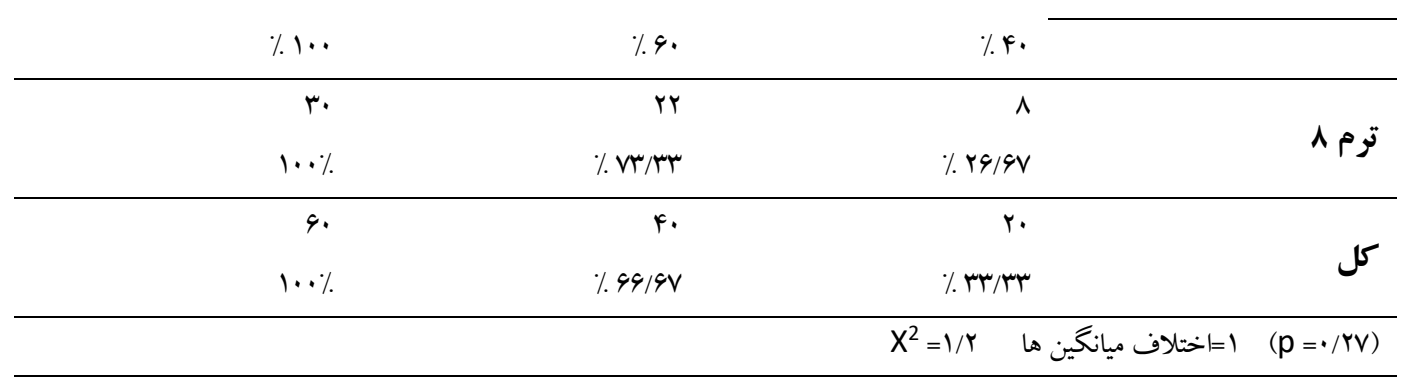

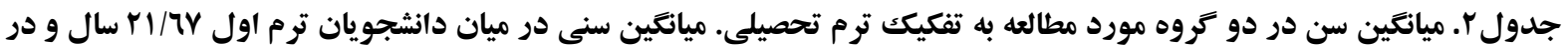

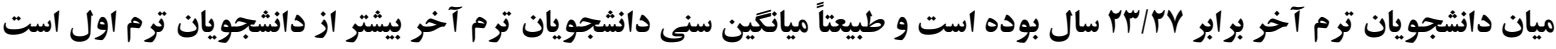
$(p=\cdot / T Y)$

\begin{tabular}{|c|c|c|c|c|}
\hline \multicolumn{5}{|c|}{ ميانغين سن در دو كروه } \\
\hline بيشترين & كمترين & انحر اف معيار & ميانغين سن & ترم تحصيلى \\
\hline YF & 19 & $1 / 01$ & $r I / 9 V$ & ترم 1 \\
\hline ro & rr & $\cdot / N F$ & $r H / T V$ & ترم \\
\hline
\end{tabular}

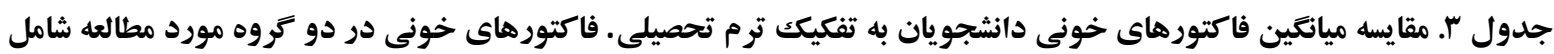

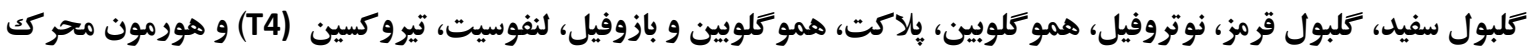

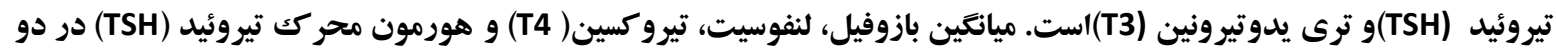

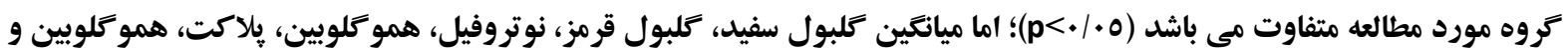

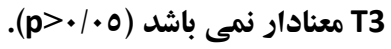

\begin{tabular}{|c|c|c|c|c|c|c|c|c|}
\hline & & & & \multicolumn{5}{|c|}{ مقايسه ميانكين فاكتورهاى خونى بين دانشجويان ترم ا و ترم ^ } \\
\hline & $\tau^{b}$ & \multirow{2}{*}{ هاختكين } & \multirow[b]{2}{*}{$\mathbf{t}$} & \multicolumn{2}{|r|}{ 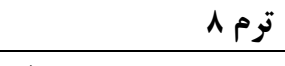 } & \multicolumn{2}{|r|}{ ترم ا } & \multirow[b]{2}{*}{ 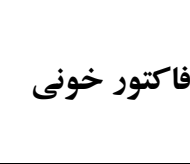 } \\
\hline نتيجه & معنادارى & & & انحـــــــــاف & ميانغين & انحر اف & ميانكين & \\
\hline اختلاف معنىدار نيست. & $\cdot / M F$ & $\Delta \wedge$ &.$/ 99$ & $1 / 4 \pi$ & G/Ar & $1 / 49$ & G/FV & كلبول سفيد \\
\hline اختلاف معنىدار نيست. & $\cdot / I V$ & $\Delta \wedge$ & $1 / \pi V$ & $\cdot / 9$ & $\varphi / \Lambda$. & $\cdot / 4 \Delta$ & $4 / 99$ & كلبول قرمز \\
\hline 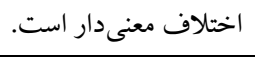 & $\cdot / \cdot r$ & $\Delta \wedge$ & $r / r)$ & $\cdot / I V$ & .190 &.$/ 19$ & $\cdot / \Delta F$ & 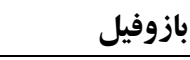 \\
\hline 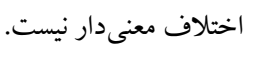 & $\cdot / \mathrm{V} \Lambda$ & $\Delta \Lambda$ & $\cdot /{ }_{\Lambda}$ & $1 / r$ & $r / 9$. & $|/ \mu|$ & $r / 99$ & 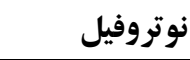 \\
\hline 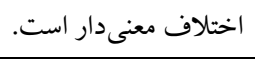 & $\cdot / \cdot r$ & $\Delta \Lambda$ & $\mu / \cdot V$ & $\cdot / 49$ & $r / \Delta \Lambda$ & $\cdot / \Delta F$ & $r / 19$ & لنفوسيت \\
\hline 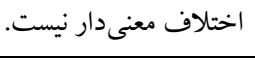 & $\cdot / \cdot \wedge$ & "DI & $1 / \wedge 1$ & $1 / \cdot v$ & $1 \pi / r$. & $1 / \Delta \Lambda$ & Ir/Ar & 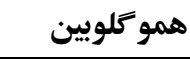 \\
\hline اختلاف معنى دار نيست. & $\cdot / 94$ & * $\Delta V$ &.$/ .9$ & $F q / Y$. & rrD/ar & $F r / Y$. & $M H F / \Delta V$ & 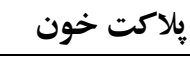 \\
\hline اختلاف معنى دار نيست. & $\cdot / r$ & $\Delta \wedge$ & $1 / \Delta V$ & $r q / 9 \Delta$ & $10 \Lambda / \cdot 1$ & $r V / \cdot q$ & $\mid \& G / \Delta r$ & 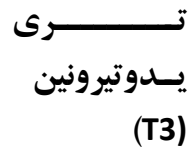 \\
\hline اختلاف معنىدار است. & .1 .49 & $\Delta \wedge$ & $r / \cdot F$ & 1/r & $\Lambda / 9 \mathrm{~V}$ & $\cdot / \wedge \Delta$ & $\Lambda / 11$ & 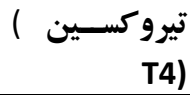 \\
\hline
\end{tabular}




\begin{tabular}{|c|c|c|c|c|c|c|c|c|}
\hline اختلاف معنىدار است. & $\cdot 1 \cdot 1$ & $\Delta \Lambda$ & $r / 91$ & $\cdot / 9 F$ & $r / 9 Y$ & $\cdot / V F$ & $r / I r$ & 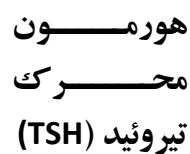 \\
\hline اختلاف معنىدار نيست. & $\cdot / 1 \mathrm{~V}$ & $\Delta \Lambda$ & $1 / T V$ & $r / r$ & $F Y / F$ & $F / l$ & $\mathrm{Fr} / \mathrm{D}$ & هماتوكريت \\
\hline
\end{tabular}

توسط سلطان و همكارانش انجام شد در اين مطالعه ·F نفـر

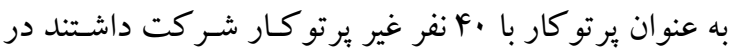
ير تو كاران در مقايسه با افراد سـالم تفـاوت معنـادار تنها در لهر

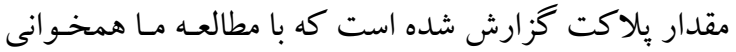

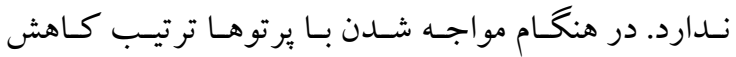
سـلولهاى خــونى بــــين ترتيـب اسـت ابتــدا لنفوسـيت،

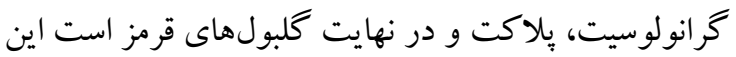
احتمال وجود دارد كه با توجه به مقاوم بودن يُاكت ها، در دانشجويان ميزان برتو در حـد كاهش ايـن سـلولها نبوده

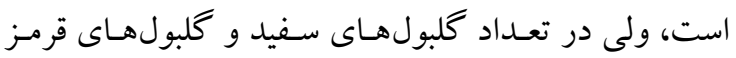

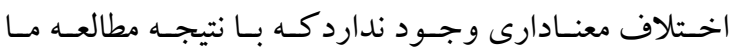
همخو انى دارد (ها ). در مطالعات سيتوزنتيكك انجام شـده در

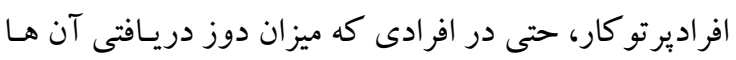

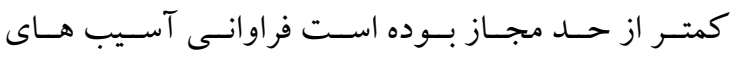

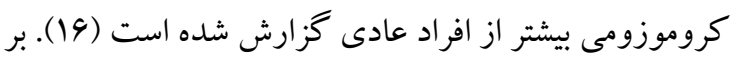
اساس نتايج به دست آمده از يثزوهش دردانشجويان ترم آخر

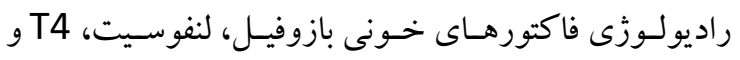

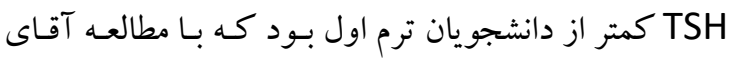
كوينك و همكار انش همخوانى داشت. در مطالعه مى مذكور

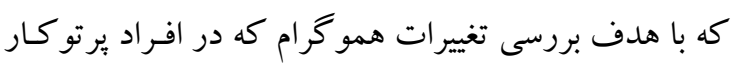

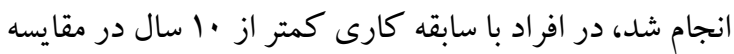

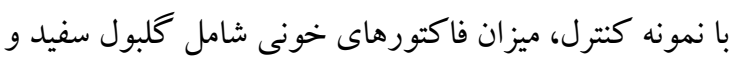

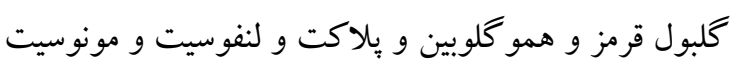

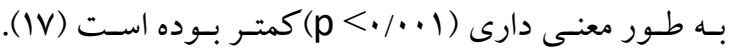

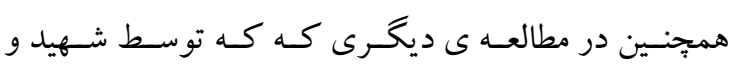
همكارانش با هدف بررسى اثر دوزهاى كم يرتوهاى يونيزان روى بارامترهاى خونى تكنولوزيست هاى شاغل انجام شـد،

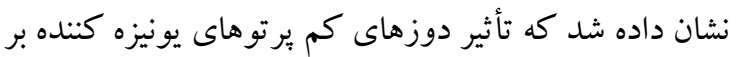

دانشجويان رشته راديولوزى در طول مدت تحصيل خود بنـا بر وجود واحدهاى كار آموزى از همان ترمهاى آغـازين در معرض اثرات مزمن ناشى از يرتو بهصسورت مــداوم خواهنــــ بـود و متأسـفانه در طـول ايسن مـدت مجهـز بـه تجهيـزات

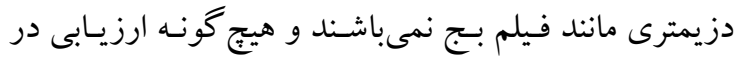

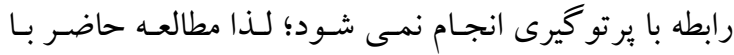
هدف بررسى و مقايسه فاكتورهاى خونى در دانشجويان ترم

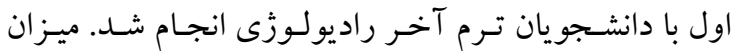

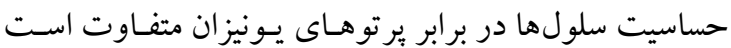
سلولهاى مغـز استخوان از جمله حسـاسترين سـلولها در بر ابـر برتسو مىباشـند (با). مـا هـم در ايسن مطالعهـ تغييـر در فاكتورهاى خونى و ميزان T3، T4 و TSH را به عنوان ابزار سنجش در باسخ به برتوهاى يونيزان بـه كـار گَرفتيم. نتـايج

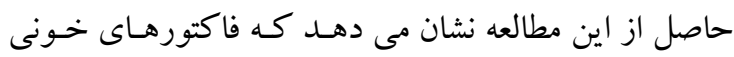

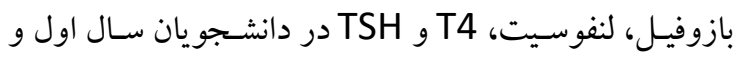
سال آخر اختلاف معنى دارى با هم دارندكه با نتايج حاصل

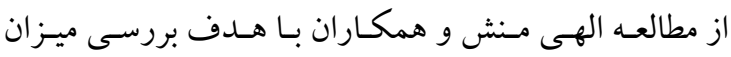

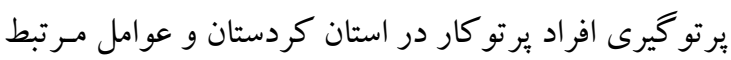
با بآن تطابق دارد. در اين مطالعه فاكتورهاى خونى افراد شـامل كلبـول سـفيد،

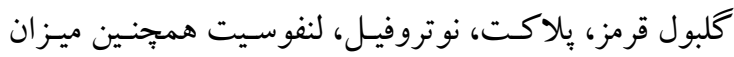

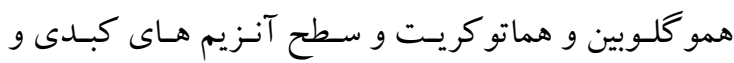

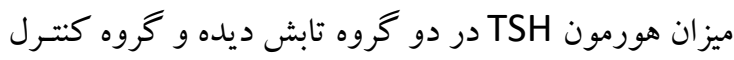

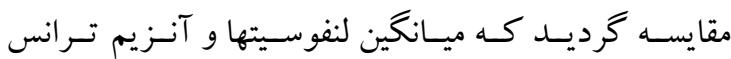

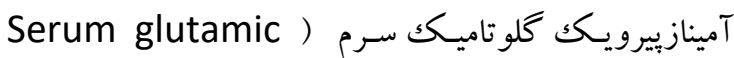
(pyruvic transaminase, SGPT

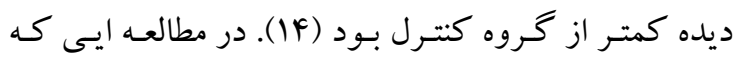


با نتيجه مطالعه ما همخوانى دارد. دليل عدم وجود ارتباط در

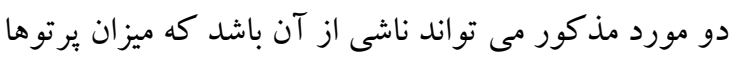

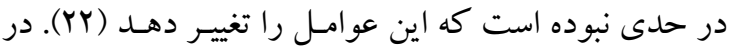

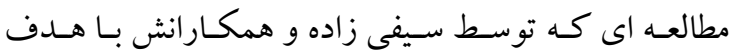
بررسى تغييرات فاكتورهاى خونى و ارتباط آن با نوع گركروه

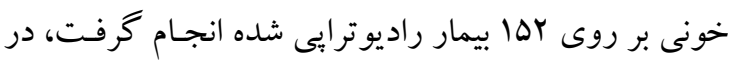

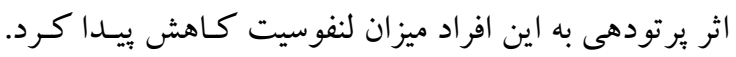

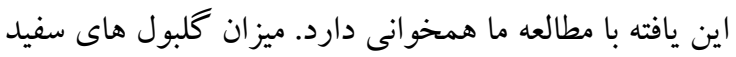

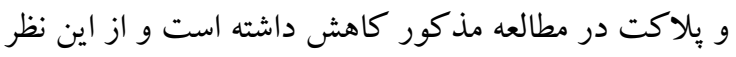
با مطالعه ما همخو انى ندارد، دليل عـدم همخـوانى مى توانـــ ناشسى از تفــاوت در رنسج انـرزى برتوهـا باشـــ. در بيمـاران

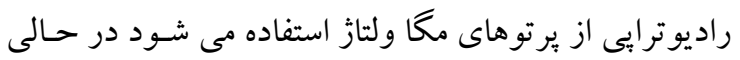

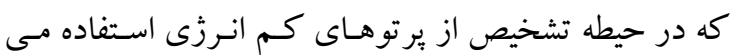
شـود (Tr). ميـزان حساسـيت سـلول هـا در برابـر يرتوهـاى يونيزان متفاوت مى باشد سلول هاى مغـز استخوان از جملهـ

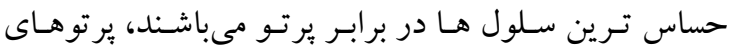

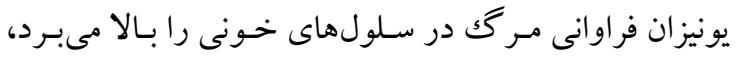
مطالعات متعددى تغييرات همـاتولوزيكى را بـه عنوان ابزار سنجش جهت برتو گيرى به كار گرفته انـد. شـمارش سـلول

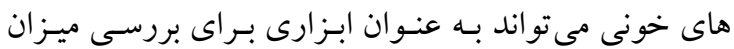
آسيبهاى يرتوهاى يونيزان بـر روى سيستم خونسـاز بــن

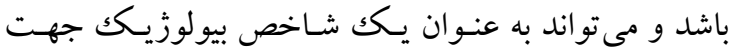
بررسى آسيب هاى ناشى از يرتوها باشد (rا). تابش برتوهاى يـونيزان بـر روى تيروئيسد باعـث تغييـر در عملكـرد تيروئيسد مىشود و باعث تغيير در ميزان ترشحات آن مى شـود. غـده تيروئيد بـه خصـوص درسـين جـوانى حساسيت زيـادى بـهـ

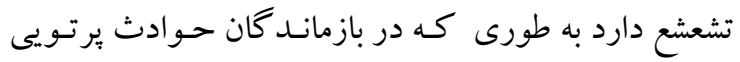
سرطان تيروئيد ديده شده است از آنجا كه اين هورمون ها از

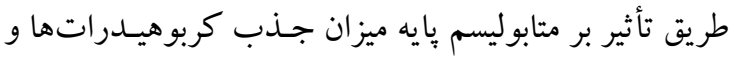

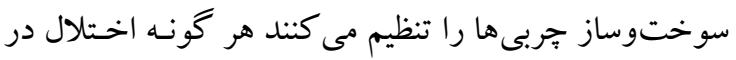

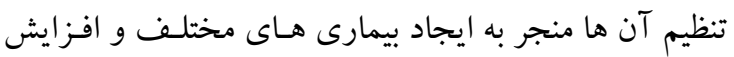

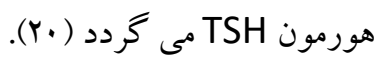

روى خـون و همجنِـين سيستم ايمنسى تكنولوزيسـت هـاى

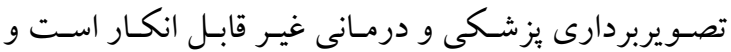
بيشترين تأثير بر روى لنفوسيت ها و بازوفيل هاى برتو كاران خواهد داشت. اين يافته ها با نتايج مطالعه ما همخوانى دارد (1)). در مطالعه اى كه توسط داووديان و همكارانش انجام شد، كلبول هاى سفيد در افراد برتو كار در مقايسه بـا گركروه

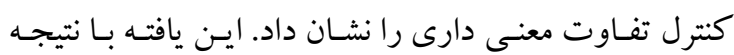
مطالعه ما همخوانى دارد. همجنين در ايسن مطالعه در ميزان كلبول هـا قرمز در دو گروه مـورد مطالعهـ شـامل كار كنـان شاغل در واحدهاى كار با يرتو با افراد نمونه كنتـرل تفــاوت معنادارى وجود نداشت. ايـن يافتـه نيـز بـا مطالعه مـا كـاملاً همخو انى دارد (19). در مطالعهاى كه توسط الهى مـنش و

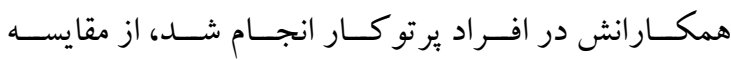

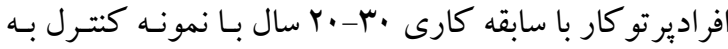
اين نتيجه رسيدند كه ميـانگين بِاكـت هـا، سطح آنزيم SGPT و هورمون TSH در گروه تابش ديده با سابقه كارى

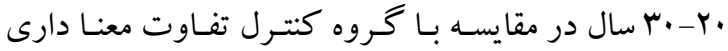

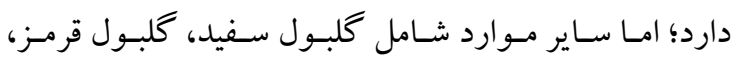
نوتروفيـل و ميـزان هماتو كريست معنسى دار نبـود. (F) (IF). در

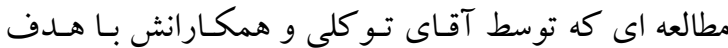
بررسى سلول هاى خونى يرتو كـاران شـاغل در بخش هـاى لـ

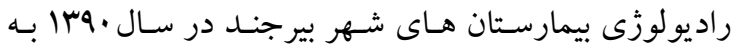
صورت مورد-شاهدى بر روى وبنفــ از برتو كـاران شـاغل در بخش هاى يرتويى و 4r نفر از كار كنان شـاغل در سـاير بخش ها انجام شد، تعداد كلبول هاى سفيد و كلبول هـاى

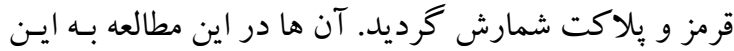
نتيجهـ رسـيدند كـه ير توهـاى يـونيز ان سـبب كـاهش تعسداد كلبولهاى سفيد به ويزه مونوسيت ها مى شود كه مى توانــ ناشى از حساسيت بالاى اين سلول ها در برابر يرتو نسبت بـه فيها

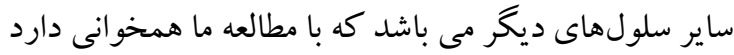

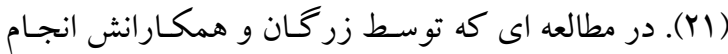

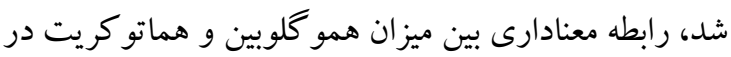
دو گروه تحت تابش و گروه شاهد وجود نداشت. اين يافتـه 


$$
\begin{aligned}
& \text { كار با يرتو در زمان كار آموزى بايد دوز سنجى دانشـويان } \\
& \text { را جهت بايش مدنظر قرار داد. } \\
& \text { تشكر و قدردانى } \\
& \text { اين مطالعه حاصل طرح تحقيقاتى مصـوب كميتـه تحقيقـات }
\end{aligned}
$$

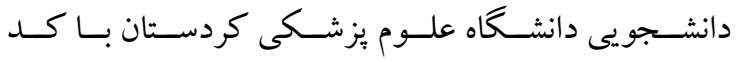

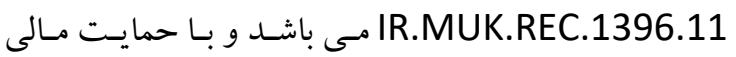

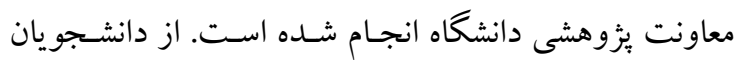

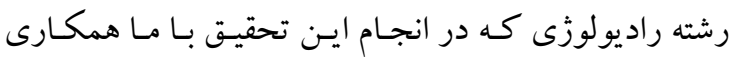

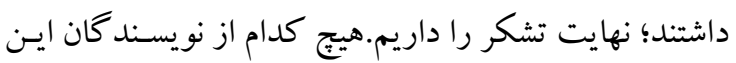

$$
\begin{aligned}
& \text { مقاله تعارض منافعى براى انتشار آن ندارند. }
\end{aligned}
$$

نتيجه كيرى

بر اساس نتايج مطالعات قبلى مشخص شده است كه دريافت

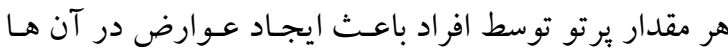
خواهد شد. در مطالعات قبلى تغييرات فاكتورهاى خـونى در

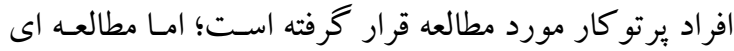
مبنى بر بررسى تغييرات خونى و هورمونى دانشجويان انجام

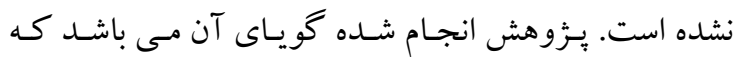

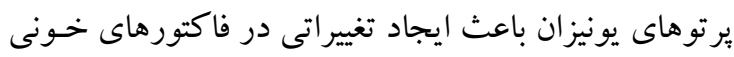

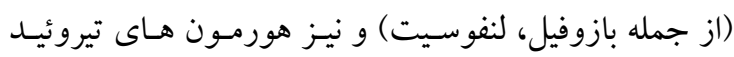

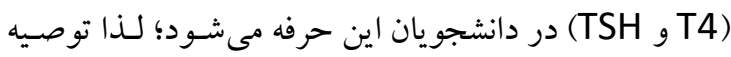

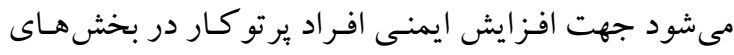

1.Baker N, Bromilow L, Costigan J. Exposure to ionising-radiation from x-rays in the intensive therapy unit-St Vincent's Hospital. Aust Crit Care. 1992;5(1):24-28

2. Takeiri A, Mishima M, Tanaka K, Shioda A, Harada A, Masumura K. Mutation Spectra in Cisplatin-and Transplatin-treated GDL1 Cells Clarified the Different Mode of Action of These Compounds in Mammalian Cells. Genes Environ. 2007;29(3):89-99.

3 Movafagh A, Maleki, F, Mohammadzadeh SG, Fadaei S. Association of glutathion Stransferase and chromosomal aberrations as a means to determine occupational exposure. In: International Congress Series. Elsevier, 2005;24 :197-198.

4. Khosravifarsani M, Monfared AS, Akhavan-Niaki H, Elahimanesh F, Borzoueisileh S, Seyfizadeh, N. The study of radiosensitivity in left handed compared to right handed healthy women. BMC Medical Physics.2012;123-130.

5. Mitchel RE. Cancer and low dose responses in vivo: implications for radiation protection. Dose-Response. dose-response. 2007; 89: 54-57.

6. Zakova M. Occupational exposure in angiography (Prague workplaces). Radiat Prot Dosimetry. 2001;94(1-2):129-32.

7. Thierens H, Vral A, Morthier R, Aousalah B, De Ridder L. Cytogenetic monitoring of hospital workers occupationally exposed to ionizing radiation using the micronucleus centromere assay. Mutagenesis. 2000;15(3):245-9.

8. Cengiz M, Gurkaynak M, Vural H, Aksoy N, Cengiz B, Yildiz F, et al. Tissue trace element change after total body irradiation. Nephron Exp Nephrol. 2003;94(1):e12-e6.

9. Barquinero J, Barrios L, Caballin M, Miro R, Ribas M, Subias A, et al. Cytogenetic analysis of lymphocytes from hospital workers occupationally exposed to low levelsof ionizing radiation. Mutat Res. 1993;286(2):275-8

10. Amirzadeh F, Tabatabaie SHR. Survey of radiation protection awareness among radiation workers in Shiraz hospitals [Persian]. Iran J Nucl Med. 2005;13(2):38-43.

11. Wojcik A, Gregoire E, Hayata I, Roy L, Sommer S, Stephan G, et al. Cytogenetic damage in lymphocytes for the purpose of dose reconstruction: a review of three recent radiation accidents. Cytogenet Genome Res. 2004;104(1-4):200-5.

12. Sherer MAS, Visconti PJ, Ritenour ER. Radiation Protection in Medical Radiography: Elsevier Health Sciences; 2017;55:48-53. 
13. Shafiee M, Rashidfar R, Borzoueisileh S, Ghorbani M, Vafapour H, Rahimi S. The Effect of occupational exposure on blood parameters of radiology staffs in Yasuj. Armaghane danesh. 2016;21(4):410-9.

14. Elahimanesh F, Allaveisi F, Zahedi R, Abdolmohammadi J, Mahmoodi M, Amiri J, et al. Evaluation of changes in blood factors, liver functional tests, and thyroid tests in radiation workers in hospitals in kurdistan province, Iran. JIMS. 2018;35(453):1532-9

15. Meo SA. Hematological findings in male x-ray technicians. SMJ. 2004;25(7):852-6.

16. Cardoso R, Takahashi-Hyodo S, Peitl Jr P, Ghilardi-Neto T, Sakamoto-Hojo E. Evaluation of chromosomal aberrations, micronuclei, and sister chromatid exchanges in hospital workers chronically exposed to ionizing radiation.TCMJ. 2001;21(6):431-9.

17. Qian QZ, Cao XK, Liu HY, Shen FH, Wang Q, Tong JW, et al. Analysis of Hemogram of Radiation Workers in Tangshan, China. J Clin Lab Anal. 2016;30(5):682-8.

18. Shahid S, Mahmood N, Chaudhry MN, Sheikh S, Ahmad N. Assessment of impacts of hematological parameters of chronic ionizing radiation exposed workers in hospitals. FUUAST J Biol. 2014;4(2):135.

19. Davoudian Talab A. Effects of occupational exposure on blood cells of radiographers working in Diagnostic Radiology Department of Khuzestan Province. IJMP.2018;15(2):6670 .

20. David S, Van Dis ML, Razmus TF, MacDonald j. Some Current Legal Issues that May Affect Oral and Maxillofacial Radiology: J Can Dent Assoc. 2007; 5-8

21. Tavakoli M, Mahmood N, Ahmad N. Evaluation of blood cell radiology workers in Brigand hospitals in2 013. J Birjand Univ Med Sci.2014;36(1):26

22. Zargan S, Seyedmehdi SM, Emami H, Attarchi M, Yazdanparast T. Comparison of blood cells in radiology workers and non-radiation workers staff of a governmental hospital in Tehran. IOH. 2016;13(4):31-8.

23..Seyfizadeh N, Saboori H, Borzoueisileh S, Habibi M, Elahimanesh F. ABO blood groups as a new potential predictive factor in radiotherapy hematological changes. Bratisl Lek Listy. 2020;121(1):67. 